\title{
demandia
}

ISSN 2477-6106 | E-ISSN 2502-2431 | http://bit.do/demandia

Jurnal Desain Komunikasi Visual, Manajemen Desain dan Periklanan

Vol. 03 No. 02 (September 2018)

\section{VISUALISASI DESAIN KARAKTER MAHASISWA JURUSAN DESAIN KOMUNIKASI VISUAL PADA PAPAN PERMAINAN KULIAH SENI \& DESAIN}

\author{
Syarip Hidayat ${ }^{1}$, Mochamad Rosidin ${ }^{2}$ \\ 1,2Program Studi Desain Komunikasi Visual, Fakultas Industri Kreatif, Telkom University \\ Jl. Telekomunikasi No. 1, Bandung, 40287 \\ syarip@telkomuniversity.ac.id ${ }^{1}$, ip23.mr@gmail.com²
}

Diterima: 27 Maret 2018

Direvisi Akhir: 18 Agustus 2018

Disetujui terbit: 4 September 2018

\begin{abstract}
Abstrak: Minat dan bakat pada setiap individu memiliki bidang yang berbeda-beda. Adapun nature dan nurture menjadi faktor yang mempengaruhi. Bakat yang dilatih dapat bermanfaat dan bisa menjadi suatu keahlian, jalur yang dipilih untuk melatih bakat dapat melalui pendidikan. Siswa yang lulus dari SMA dan sederajat biasanya dihadapkan pada dua pilihan yaitu bekerja atau meneruskan pendidikan ke perguruan tinggi. Beberapa jurusan di Indonesia yang populer dan diminati oleh para calon mahasiswa, salah satunya ialah Desain Komunikasi Visual (DKV), jurusan dengan peminat yang banyak inilah maka diperlukan untuk dikenalkan lebih jauh, Metode yang digunakan adalah metode penelitian kualitatif dengan melakukan studi literatur dan juga observasi. Hasil analisis menunjukkan bahwa Desain karakter dapat dijadikan sebagai solusi visual sebagai representasi mahasiswa jurusan ini yang kemudian digunakan pada papan permainan 'kuliah seni \& desain'. Perancangan ini berupa ilustrasi karakter pemain dalam kartu karakter pada papan permainan untuk mengenalkan lebih jauh mengenai jurusan Desain Komunikasi Visual (DKV).
\end{abstract}

Kata kunci: Desain Karakter, Desain Komunikasi Visual, Ilustrasi, Papan permainan

\begin{abstract}
Interests and talents of each individual are unique. The nature and nurture become an influencing factor. Talents that are prepared can be useful and be a skill, it can be achieved through education. Students graduating from high school and equivalent are usually faced with two choices: working or continuing their education to college. Some majors in Indonesia are popular and in demand by prospective students, one of them is Visual Communication Design (DKV), the major which needs to be introduced further. The method used is qualitative research methods by conducting literature studies and observations. The results of the analysis show that character design can be used as a visual solution as a representation of students in this department which is then used in board game 'kuliah seni \& desain'. This design is in the form of an illustration of the player
\end{abstract}

Penulis adalah staf pengajar dan mahasiswa jurusan Desain Komunikasi Visual, Fakultas Industri Kreatif Telkom University 
character on the character card of the board game in order to introduce further about the Department of Visual Communication Design (DKV).

Keywords: Board games, Character Design, Illustration, Visual Communication Design

\section{PENDAHULUAN}

Pendidikan merupakan modal awal untuk mendapatkan ilmu pengetahuan dan keahlian dalam membangun sebuah karir. Modal yang diperoleh melalui pendidikan adalah sebuah modal dalam bentuk keahlian. Untuk membangun sebuah modal karir, diperlukan waktu bertahun-tahun, kemudian diinvestasikan pada jalan karier yang diharapkan. Lebih dari sekedar mencari keahlian, pendidikan juga berperan penting dalam pembangunan karakter seseorang dan diharapkan mampu berkontribusi dalam pembangunan bangsa. Salah satu faktor penting yang mempengaruhi perkembangan sebuah negara yaitu adanya sumber daya manusia (SDM). Sumber daya manusia adalah faktor paling penting dalam proses pembangunan. Melalui pendidikanlah sumber daya manusia diolah dan dibentuk karakternya untuk menghasilkan manusia yang berkualitas dan kompeten.

Setiap individu memiliki minat dan bakat pada bidang yang berbeda-beda. Hal ini dipengaruhi oleh yang disebut para psikolog sebagai faktor nature dan nurture. Nature dapat diartikan sebagai sifat dasar atau faktor alamiah yang berhubungan dengan aspek biologis, gen, keturunan. Dengan kata lain, perkembangan minat dan bakat manusia salah satunya dipengaruhi oleh faktor keturunan. Kemudian nurture, faktor lain yang mempengaruhi perkembangan manusia, merupakan faktor eksternal atau pengaruh dari lingkungan, pola asuh, pendidikan, budaya, dan sebagainya. Dengan menyadari minat dan bakat sedini mungkin, khususnya untuk siswa sekolah menengah, diharapkan mampu mengembangkan dan mengoptimalkan potensi yang dimilikinya dengan memilih strategi belajar yang tepat atau dapat mengarahkannya pada jalur pendidikan 
(jurusan) yang relevan sesuai minat dan bakat tersebut. Pengembangan kompetensi pada bidang yang sesuai dengan minat seseorang, akan mampu melahirkan sumber daya manusia yang kompeten.

Setelah lulus dari jenjang pendidikan SMA dan sederajat, umumnya ada dua pilihan yang dimiliki oleh siswa, yaitu bekerja atau meneruskan pendidikan ke jenjang perguruan tinggi. Bagi mereka yang akan meneruskan pendidikan ke jenjang perguruan tinggi akan disibukkan dengan berbagai persiapan, di antaranya persiapan belajar untuk bersaing memasuki universitas dan jurusan yang diinginkan. Di Indonesia terdapat beberapa jurusan yang populer dan banyak diminati setiap tahunnya oleh para calon mahasiswa. Salah satu jurusan yang banyak diminati ialah jurusan Desain Komunikasi Visual (DKV). Pada dasarnya DKV merupakan turunan dari rumpun ilmu seni, namun DKV lebih bersifat fungsional.

DKV adalah disiplin ilmu yang mempelajari bagaimana mengomunikasikan sebuah pesan secara efektif dan efisien melalui visual. Jurusan DKV menjadi semakin popular karena sejalan dengan program ekonomi kreatif yang gencar dipromosikan pemerintah. Oleh karena itu, lulusan DKV menjadi lulusan yang sesuai dengan program tersebut yang bekerja pada bidang kreatif. Meskipun demikian, nyatanya masih banyak calon mahasiswa yang mengambil jurusan DKV tanpa mengetahui seperti apa medan yang akan mereka hadapi pada jurusan tersebut. Maka, diperlukan suatu gambaran melalui rancangan sebuah ilustrasi karakter yang dapat merepresentasikan mahasiswa jurusan DKV. Perancangan ini diharapkan mampu menggambarkan bagaimana penampilan mahasiswa Desain Komunikasi Visual yang kemudian digunakan sebagai ilustrasi pemain pada papan permainan kuliah seni dan desain.

\section{KAJIAN TEORI}

Ilustrasi merupakan penggambaran sebuah pesan yang disampaikan melalui gambar visual. Ilustrasi menurut Kusmiati R. (dalam Jamal dkk, 2015:43) merupakan suatu cara untuk memunculkan sebuah perasaan atau efek dengan 
memperlihatkan subjek dengan tujuan menginformasikan bentuk atau gambar suatu produk yang belum pernah ada, mencoba menggambarkan ide abstrak, menunjukan sebuah peristiwa yang agak mustahil, memperjelas isi pesan, atau menerangkan sesuatu secara detail.

Ilustrasi memiliki berbagai fungsi baik itu Fungsi deskriptif, fungsi ekspresif, fungsi analitis atau struktural dan fungsi kualitatif (Kusrianto, 2009: 70-71) perancangan karakter visual ini menggunakan fungsi ekspresif untuk menyatakan ilustrasi karakter yang dirancang untuk menyatakan gagasan, maksud dan konsep yang mudah dipahami oleh pembaca.

Dalam perancangan karakter diperlukan unsur-unsur visual dalam mendukung penyampaian pesan, menurut Scott McCloud (2008:4), untuk dapat menghubungkan rancangan karakter yang divisualisasikan untuk pembaca oleh seniman dapat melalui ekspresi wajah, dan bahasa tubuh. Suatu rancangan karakter juga memerlukan karakter yang memiliki ciri khas dan kepribadian, ekspresi wajah dalam memotret emosi, bahasa tubuh untuk menyampaikan sebuah cerita (McCloud,2008:62). Tiga ciri lain dalam merancang karakter adalah jiwa, ciri khas dan sikap ekpresi (McCloud, 2008:63). Oleh karena itu desain karakter bisa digunakan untuk memberikan visualisasi melalui representasi dan penggambaran suatu objek untuk dapat menampilkan pesan.

Desain karakter ditampilkan secara visual, tampilan visual lebih mudah memberikan informasi seperti yang dipaparkan Alina Wheeler bahwa Indera penglihatan memberikan lebih banyak informasi tentang dunia dibandingkan dengan panca indera lainnya (Wheeler, 2013 dalam Haiqal dan Hidayat, 2017:185).

Kajian teori di atas menjadi acuan dalam perancangan desain karakter mahasiswa Desain Komunikasi Visual, di mana karakter merupakan ilustrasi dalam menginformasikan bentuk atau gambar. Karakter memerlukan unsur-unsur visual supaya pesan dapat tersampaikan dengan baik. Desain karakter ini kemudian 
dapat digunakan sebagai ilustrasi pemain pada papan permainan kuliah seni dan desain.

\section{METODE PENELITIAN}

Metode yang digunakan dalam penelitian ini menggunakan metode penelitian kualitatif. Penelitian kualitatif menurut Creswell (2010: 4) adalah suatu metode untuk mengeksplorasi kemudian dapat memahami makna dari sejumlah individu maupun sekelompok orang yang berasal dari masalah sosial ataupun kemanusiaan.

Metode pengumpulan data dalam penelitian kualitatif adalah data yang bukan dalam angka, namun berupa teks, gambar, dokumen, foto, artefak atau obyek lain yang ditemukan pasa saat berada di lapangan (Sarwono dan Lubis, 2007:100) melalui studi pustaka dan observasi. Pengumpulan data dilakukan dengan studi pustaka pada informasi yang relevan yang diperoleh dari buku, artikel, jurnal, dan karya ilmiah. Informasi yang relevan tersebut berkaitan pula dengan visualisasi karakter diambil berupa analisis visual jenis ilustrasi yang dijadikan sebagai referensi penggayaan visual yang dipilih.

Observasi dilakukan pengamatan terhadap objek yang diteliti dalam situasi yang sebenarnya. Observasi lapangan dilakukan pada mahasiswa Seni Rupa dan Desain terutama mahasiswa Desain Komunikasi Visual di Universitas Telkom Bandung. Observasi mengambil visualisasi baik penggayaan dari desain karakter yang akan dibuat, dan juga atribut yang digunakannya serta perlengkapan perkuliahan yang dibawa.

\section{HASIL DAN DISKUSI}

Desain karakter dapat dijadikan sebagai solusi visual seperti dipaparkan pada kajian teori bahwa karakter merupakan ilustrasi dalam menginformasikan bentuk atau gambar, dan ilustrasi karakter secara visual dapat menyampaikan 
pesan dengan baik sebagai representasi dalam hal ini penggambaran mahasiswa desain komunikasi visual. Desain karakter ini kemudian dapat digunakan sebagai ilustrasi pemain pada papan permainan kuliah seni dan desain.

Desain karakter harus mampu menjelaskan seperti apa karakter tersebut, latar belakang dari karakter tersebut melalui atribut yang digunakannya, bahkan penggayaan dari desain karakter tersebut harus dapat menjelaskan jenis ilustrasinya apakah kasual, serius, kartun, semi realis, ataupun realis. Penentuan karakter diperlukan analisis melalui analisis gaya visual dan gaya warna dalam pengambaran ilustrasi karakter agar sesuai dengan khalayak sasaran.

Tabel 1 Analisis Referensi Studi Visual Karakter

\begin{tabular}{|c|c|c|}
\hline Gambar & Gaya Visual & Gaya Warna \\
\hline & 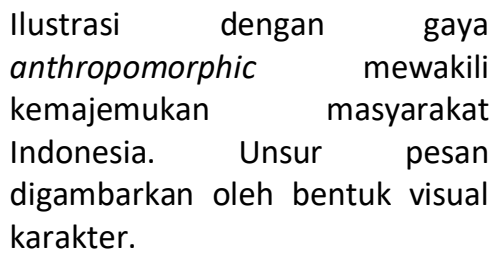 & $\begin{array}{l}\text { Warna sederhana, tidak banyak } \\
\text { skema warna yang digunakan, } \\
\text { hanya mengguakan warna utama } \\
\text { dan shading, minim highlight. }\end{array}$ \\
\hline & $\begin{array}{l}\text { Animasi gaya Eropa dan Disney } \\
\text { yang tidak realis, memiliki kesan } \\
\text { fantasi, dapat masuk untuk } \\
\text { kalangan anak-anak hingga } \\
\text { remaja. }\end{array}$ & $\begin{array}{l}\text { Warna sederhana minim shading, } \\
\text { teknik warna menggunakan } \\
\text { warna analogus. }\end{array}$ \\
\hline & $\begin{array}{l}\text { Gaya Ilustrasi sederhana, } \\
\text { dilengkapi atribut pakaian adat } \\
\text { yang berasal dari berbagai suku di } \\
\text { Indonesia. Gaya seperti ini } \\
\text { menunjukan target audience } \\
\text { anak-anak. }\end{array}$ & $\begin{array}{l}\text { Didominasi warna warna yang } \\
\text { cerah dan menarik mata, hal ini } \\
\text { disesuaikan dengan karakter } \\
\text { anak-amal yang ceria dan penuh } \\
\text { semangat. }\end{array}$ \\
\hline & $\begin{array}{l}\text { Gaya Penggambaran yang realis } \\
\text { memberikan kesan yang lebih } \\
\text { serius, ilustrasi yang disesuaikan } \\
\text { dengan konsep pesan perjuangan. }\end{array}$ & $\begin{array}{l}\text { Warna cenderung gelap untuk } \\
\text { memunculkan perasaan serius, } \\
\text { menesuaikan dengan tema } \\
\text { perang/perjuangan. }\end{array}$ \\
\hline
\end{tabular}

Sumber: Mochamad Rosidin, 2018 
Tabel Analisis Referensi Studi Visual Karakter di atas dipergunakan sebagai pertimbangan visualisasi yang akan dibuat dalam perancangan karakter ini. Analisis yang dilakukan dengan memaparkan gaya visual dan gaya warna, di mana ada empat gaya visual diantaranya gaya anthropomorphic, gaya Eropa, gaya ilustrasi sederhana, dan gaya penggambaran yang realis. Pada analisis gaya warna pun terdapat perbedaan dari setiap gaya gambar tersebut kencedurangan warna cerah dan warna gelap, gaya visual dan gaya warna ini berkaitan pula dengan khalayak sasarannya, dan pesan yang akan disampaikan pada khalayak sasaran tersebut.

\section{Konsep Perancangan}

Pada pengumpulan data melalui observasi lapangan dan analisis referensi studi visual karakter yang telah dilakukan sebelumnya, proses observasi lapangan didapatkan foto mahasiswa yang dijadikan rujukan sehingga memunculkan Konsep perancangan desain karakter dibuat dengan kesesuaian karakter usia calon mahasiswa (usia remaja 17-19 tahun). Studi pada Desain karakter disesuaikan dengan perilaku remaja, yakni kasual untuk memunculkan kesan santai. Hasil observasi menunjukan penggambaran karakter seorang laki-laki, berkacamata, berperawakan ramping, ditumbuhi kumis dan janggut tipis sedang memegang sebuah pensil dan sketchbook. 


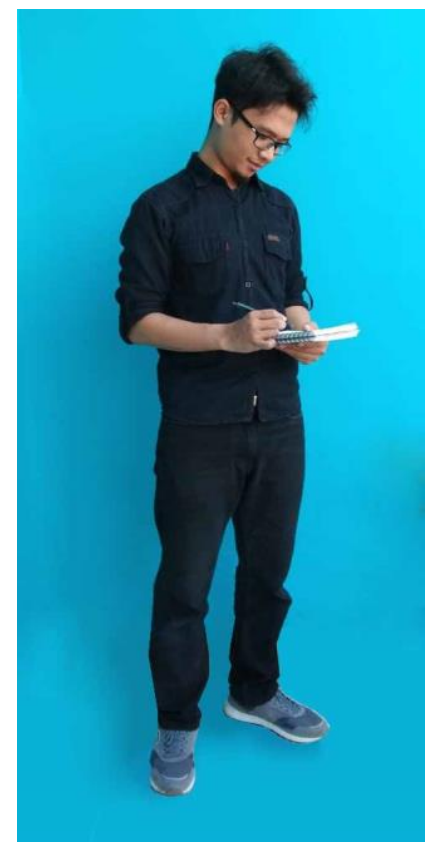

Gambar 1. Foto hasil observasi Mahasiswa Desain Komunikasi Visual Sumber: Syarip Hidayat \& Mochamad Rosidin, 2018
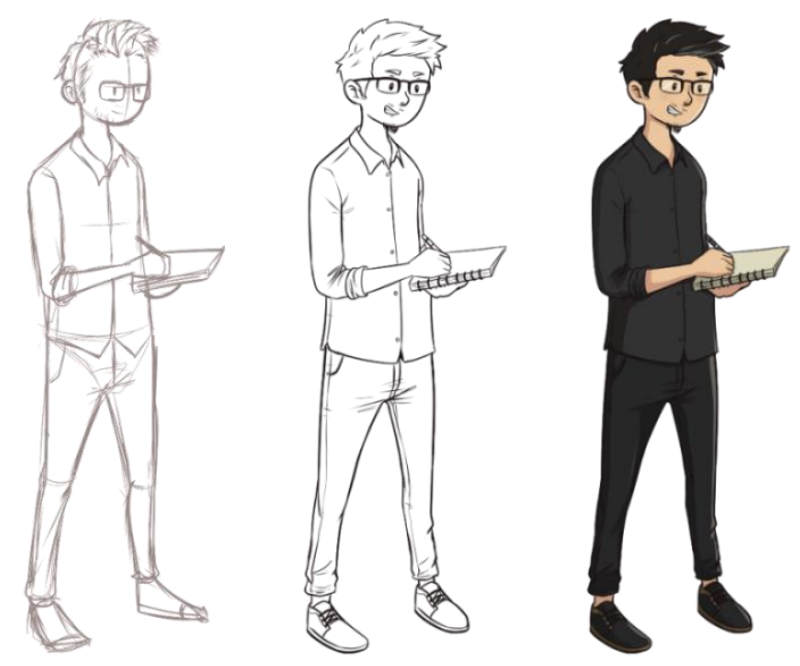

Gambar 2. Rancangan Ilustrasi karakter Mahasiswa Desain Komunikasi Visual Sumber: Mochamad Rosidin, 2018

Proses perancangan ilustrasi karakter ini, masuk kedalam proses penggambaran berupa sketsa kasar, sketsa halus, dan proses pewarnaan. Penggambaran ini dibuat untuk memberikan pesan bahwa seorang mahasiswa 
DKV bisa saja mendapatkan ide dan inspirasi dimana saja, maka dengan selalu membawa kedua atribut tersebut. Seorang desainer komunikasi visual akan selalu siap mencatat ide-ide yang muncul dalam pikirannya. Kemudian karakter ini juga digambarkan menggunakan kacamata sebagai simbol bahwa desainer komunikasi visual harus selalu cermat dalam menganalisis fenomena di sekitarnya, karena desainer merupakan salah satu agen perubahan melalui desainnya.
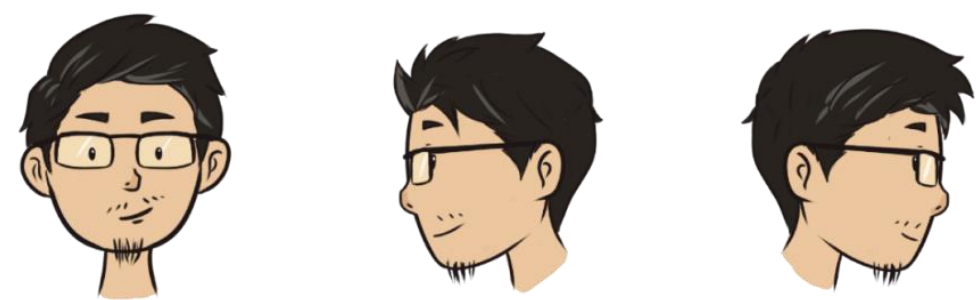

Gambar 3. Desain karakter tampak Depan dan Samping

Sumber: Mochamad Rosidin, 2018

\section{Hasil Perancangan}

Konsep perancangan sebelumnya, memaparkan mengenai konsep dan juga proses perancangannya, kemudian karakter mahasiswa yang berkuliah pada jurusan Desain Komunikasi Visual ini diberi nama Dani Defis. Defis diambil dari singkatan 'Desain Grafis' yang merupakan sub rumpun ilmu dari program studi di desain komunikasi visual. Pemberian nama tersebut berkaitan dengan berbagai informasi akademis pada jurusan desain komunikasi visual dan juga desain grafis yang disampaikan dalam papan permainan kuliah seni dan desain, terutama untuk mengenalkan lebih jauh kepada calon mahasiswa mengenai jurusan Desain Komunikasi Visual (DKV). 


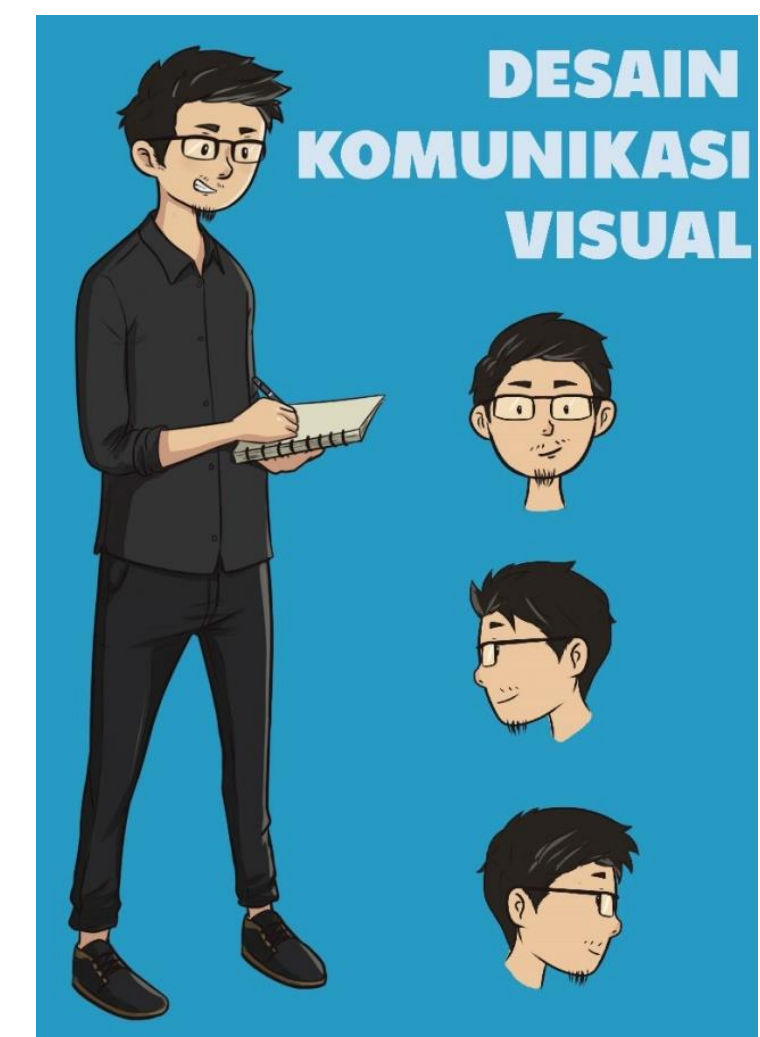

Gambar 4. Hasil Desain Karakter Desain Komunikasi Visual Sumber: Mochamad Rosidin, 2018

Pada papan permainan ini calon mahasiswa bisa berperan sebagai seorang mahasiswa yang sedang menempuh studi pada jurusan Desain Komunikasi Visual, mulai dari awal berkuliah, proses saat berkuliah baik akademis maupun non akademis. Desain karakter ini pada papan permainan masuk ke dalam kartu karakter di mana pemain bisa mengetahui proses perkuliahannya melalui kartu desain karakter ini. Pada kartu karakter terdapat keterangan setiap matakuliah yang harus ditempuh pada setiap tingkatnya. Saat pemain menyelesaikan setiap tingkatnya, ikon desain karakter yang berbentuk bulat dapat dipindahkan ke tingkat yang lebih tinggi. Untuk lebih jelas, kartu karakter dapat dilihat pada gambar 5 . Kartu karakter ini berguna supaya pemain dapat mengetahui proses perkuliahan pada jurusan desain komunikasi visual melalui papan permainan ini. 


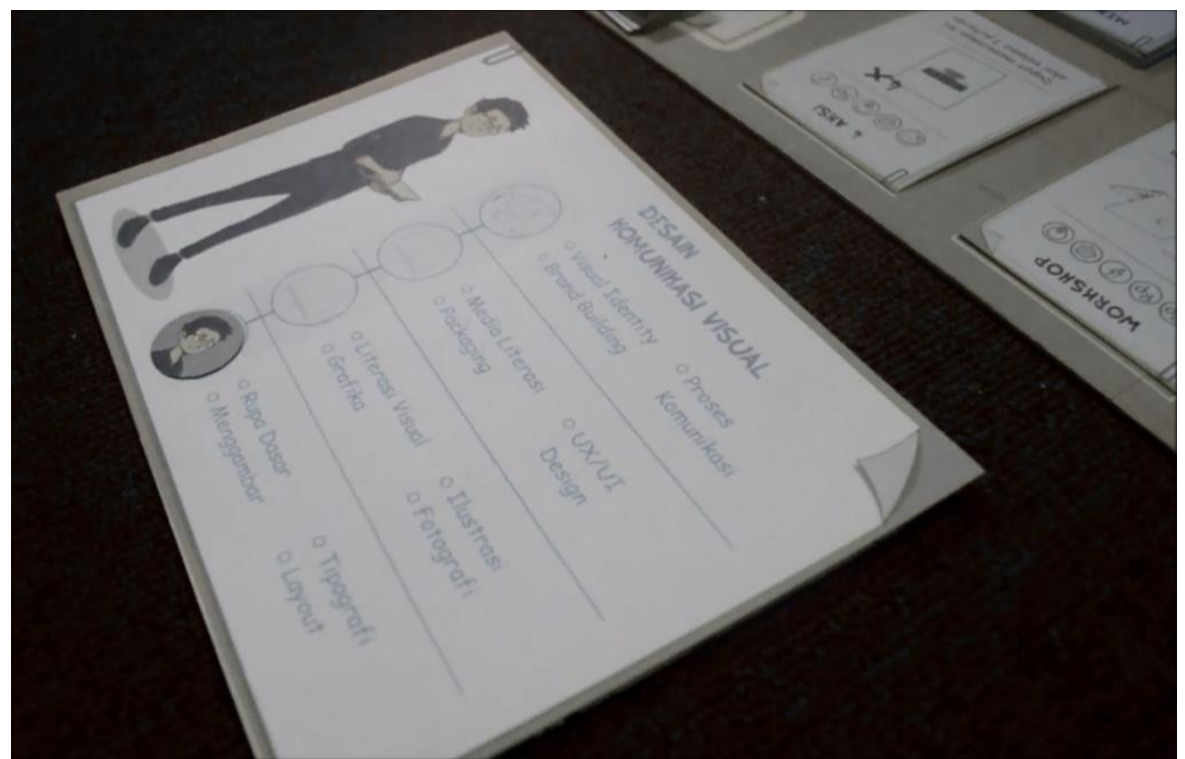

Gambar 5. Desain Karakter diaplikasi pada papan permainan di kartu karakter Sumber: Syarip Hidayat \& Mochamad Rosidin, 2018

\section{KESIMPULAN}

Desain Komunikasi Visual (DKV) merupakan jurusan yang banyak diminati oleh para calon mahasiswa. Calon mahasiswa perlu mendapatkan informasi berbagai hal mengenai Desain Komunikasi Visual sehingga perancangan desain karakter ini digunakan sebagai desain kakater pada kartu karakter yang mengilustrasikan pemain sebagai calon mahasiswa pada papan permainan kuliah seni \& desain. Papan permainan tersebut berisi tentang simulasi berkuliah pada seni dan desain yang bisa memberikan gambaran kepada calon mahasiswa mengenai hal yang berkaitan dalam berkuliah di seni dan desain terutama Desain Komunikasi visual (DKV). DKV sendiri merupakan disiplin ilmu yang mempelajari bagaimana mengemas pesan secara efektif dan efisien melalui tampilan visual.

Perancangan karakter yang diaplikasi pada papan permainan kuliah seni dan desain ini dapat menjadikan calon mahasiswa untuk mengetahui dan mempersiapkan diri dalam perkuliahan pada jurusan desain komunikasi visual. Dengan pengetahuan dan persiapan yang diketahui melalui papan permainan ini, diharapkan calon mahasiswa dapat memiliki kemampuan analitis yang kuat 
terhadap fenomena yang ada di sekitarnya untuk kemudian diselesaikan dengan cara kreatif dan inovatif.

Desain karakter pada permainan ini berpeluang pula dikembangkan pada papan permainan untuk fakultas dan jurusan lainnya, sehingga calon mahasiswa mengetahui dan mempersiapkan diri dalam perkuliahan yang akan dihadapi dengan melakukan simulasi perkuliahan melalui papan permainan jurusan lainnya.

\section{DAFTAR PUSTAKA}

Creswell, J. W., 2010. Research design: pendekatan kualitatif, kuantitatif, dan mixed. Yogjakarta: PT Pustaka Pelajar.

Haiqal, M. K., \& Hidayat, S., 2017. PENERAPAN IDENTITAS VISUAL PADA MEDIA PROMOSI WEBSITE WISATA KERAJINAN RAJAPOLAH. Jurnal Desain Komunikasi Visual, Manajemen Desain dan Periklanan Demandia 2 (2) p187

Kusrianto, Adi, 2009. Pengantar Desain Komunikasi Visual. Yogyakarta: ANDI.

Jamal, J. N., Nugraha, N. D., \& Wahab, T., 2015. Game Sang Pemimpin Untuk Memunculkan Nilai-Nilai Kepemimpinan Pada Remaja. eProcceding of Art \& Design, Vol 2, No 1 p77.

McCloud, Scott, 2008. Membuat Komik Cetakan ke 2. Jakarta: Gramedia Pustaka Utama.

Sarwono, J., \& Lubis, H., 2007. Metode riset untuk desain komunikasi visual. Yogyakarta: Andi. 